TITLE:

\title{
A Bayesian meta-analytic approach for safety signal detection in randomized clinical trials(Abstract_要旨 )
}

\section{AUTHOR(S):}

Odani, Motoi

\section{CITATION:}

Odani, Motoi. A Bayesian meta-analytic approach for safety signal detection in randomized clinical trials. 京都大学, 2017, 博士(社会健康医学)

ISSUE DATE:

2017-03-23

URL:

https://doi.org/10.14989/doctor.k20289

\section{RIGHT:}

学位規則第9条第2項により要約公開; 許諾条件により本文は2018-04-01に公開; Motoi Odani, Satoru Fukimbara, Tosiva Sato, A Bayesian meta-analytic approach for safety signal detection in randomized clinical trials, Clinical Trials (Vol 14, Issue 2) pp. 192 - 200. Copyright The Author(s) 2017. Reprinted by permission of SAGE Publications. doi: $10.1177 / 1740774516683920$ 


\begin{tabular}{|l|l|c|c|}
\hline 京都大学 & $\begin{array}{l}\text { 博士（社会健康医学） } \\
\text { 論文題目 }\end{array}$ & $\begin{array}{l}\text { A 名 } \\
\text { A Bayesian meta-analytic approach for safety signal detection in } \\
\text { randomized clinical trials } \\
\text { (臨床試験データに基づいて安全性シグナルを検出するベイズ流メタアナリ } \\
\text { シスアプローチ) }\end{array}$ \\
\hline (論文内容の要旨）
\end{tabular}

背景：メタアナリシスは有害事象データに対してしばしば用いられ、その主要 な目的は安全性シグナルの検出力を向上させることである。しかしながら、新 薬の承認申請における医薬品の安全性評価においては、複数の臨床試験からの 有害事象データを単純にプールする方法が通常用いられている。

目的 : 複数のランダム化臨床試験からの有害事象データに関する階層構造を考慮 して、新規の階層的なべイズ流メタアナリシスアプローチを提案する。

方法 : ベイズ流メタアナリシスモデルを構築するために、既存の 3 段階のベイズ階層モ デルを拡張し、臨床試験のレベルの階層を追加した。タダラフィルの 3 つのランダム化臨 床試験からの有害事象データ及びそのデータ構造を模したシミュレーションデータに提 案するベイズ流メタアナリシスモデルを適用し、提案モデルの特性を評価した。

結果 : 提案モデルは 4 段階のベイズ階層モデルとなった。ベイズ流メタアナリシスモデ ルからの結果と単純にプールしたデータに対する Fisher の正確確率検定からの結果を比 較したところ、治療との関連の強さについて上位 10 位までに順位付けられた有害事象の うち 6 つの有害事象が共通していた。しかしながら、ベイズ流メタアナリシスモデルでは Fisher の正確確率検定と比較して、「筋骨格系および結合組織障害」の器官別大分類に 所属する有害事象を数多く検出した。さらに、ベイズ流メタアナリシスモデルからの事後 オッズ比の中央值と単純にプールしたデータから計算されたオッズ比を比較すると、事後 オッズ比の中央值はほとんどの有害事象について治療との関連がない值に縮小推定され ていた。シミュレーション研究の結果から、ベイズ流メタアナリシスモデルは Fisher の 正確確率検定と比較して、誤検出確率と検出力の適切なバランスを保つことができること が示唆された。例えば、シグナル検出のためのベイズ流事後確率の閾值を 0.8 と設定した とき、ベイズ流メタアナリシスモデルでは誤検出確率が $41 \%$ で検出力が $88 \%$ であった一 方、Fisher の正確確率検定では誤検出確率が $56 \%$ で検出力が $86 \%$ であった。

考察:これらの結果はベイズ流メタナリシスモデルが実際のデータに依存して器官別大分 類の内外からの情報を利用可能であることによると考えられる。シグナル検出のためのべ イズ流事後確率の閾值は偽陽性と偽陰性の確率のバランスに対寸る要求に依存寸るが、本 データ構造に類似した有害事象データであれば、シグナル検出規則として 0.9 と設定する ことが可能であると考えられる（誤検出確率：6\%、検出力 $63 \%$ )

研究の限界：ベイズ流メタアナリシスモデルが有効であるためには、有害事象の 階層構造及び分類の妥当性が重要である。

結論：提案したベイズ流メタアナリシスモデルを用いることで、試験の違いによ る交絡を避けるために試験の効果を考慮することができ、有害事象の階層構造を 考慮することによって効果の指標の合理的かつ安定した推定值を得ることが可能 となる。

\section{（論文審査の結果の要旨）}

複数の臨床試験からの有害事象データに関する階層構造を考慮して、新規の階層的な ベイズ流メタアナリシスアプローチが提案された。ベイズ流メタアナリシスモデルを構 築するために、既存の 3 段階のベイズ階層モデルを拡張し、臨床試験のレベルの階層を 追加した。タダラフィルの 3 つのランダム化臨床試験からの有害事象データ及びそのデ 一タ構造を模したシミュレーションデータに提案モデルを適用し、その特性が評価され た。ベイズ流メタアナリシスモデルでは通常用いられている Fisher の正確確率検定と比 較して、「筋骨格系および結合組織障害」の器官別大分類に所属する有害事象を数多く 検出した。さらに、シミュレーション研究の結果から、ベイズ流メタアナリシスモデルは Fisher の正確確率検定と比較して、誤検出確率と検出力の適切なバランスを保つことが できることが示唆された。本研究の限界としては、提案モデルが有用であるためには有害 事象の階層構造や分類が妥当である、という仮定が必要な点が挙げられる。階層構造が妥 当であれば、提案したベイズ流メタアナリシスモデルで有害事象の階層構造を考慮する ことによって、効果の指標の合理的かつ安定した推定值を得ることが可能となる。

以上の研究は、臨床試験で収集される有害事象データに対するベイズ流メタアナリシ スの新しい方法を提案することで方法論の発展に貢献し、医薬品の安全性評価に寄与す るところが大きい。

したがって、本論文は博士 (社会健康医学) の学位論文として価值あるものと認める。

なお、本学位授与申請者は、平成 29 年 1 月 12 日実施の論文内容とそれに関連し た試問を受け、合格と認められたものである。 